\title{
Breeding biology and conservation of the Marsh Seedeater Sporophila palustris
}

\author{
JEFERSON VIZENTIN-BUGONI, JUAN I. ARETA, ALEJANDRO G. DI \\ GIACOMO, ADRIAN S. DI GIACOMO, FERNANDO JACOBS, \\ MARCO A. AFONSO COIMBRA and RAFAEL A. DIAS
}

\section{Summary}

The Marsh Seedeater Sporophila palustris is one of the most endangered and least known of the capuchino seedeaters. Breeding populations are patchy, occurring in north-east Argentina, southern Brazil, and Uruguay. We present data on the breeding biology of the species, and describe nests and eggs, behaviour (including courtship, nesting, incubation and parental care), breeding sites and food items. Marsh Seedeaters breed in well-preserved grasslands with wet soils and tall vegetation. In general, these habitats are used for extensive livestock ranching. Main threats are overgrazing, widespread use of fire, conversion of grasslands to pastures of exotic grasses and rice fields, afforestation, and illegal trapping. Most breeding sites are located in Important Bird Areas, but only one in Brazil and one in Argentina are protected. We propose a series of actions to promote the conservation of Marsh Seedeaters and other endangered birds that coexist in grassland habitats.

\section{Resumen}

El Capuchino Pecho Blanco Sporophila palustris es uno de los capuchinos menos conocidos y uno de los más amenazados. Sus poblaciones reproductivas son locales, fragmentadas y ocurren en el nordeste de Argentina, sudeste de Brasil y en Uruguay. Presentamos datos reproductivos describiendo nidos y huevos, comportamiento (incluyendo cortejo, nidificación, incubación y cuidado parental), sitios de anidación y datos sobre alimentación. El Capuchino Pecho Blanco nidifica en pastizales altos y húmedos en buen estado de conservación. Estos hábitats en general se han convertido en áreas ganaderas. Las principales amenazas son sobrepastoreo, uso generalizado del fuego, drenaje de humedales, reemplazo total del hábitat por pasturas y forestaciones y captura ilegal. La mayoría de los sitios se localizan en AICAs, pero sólo uno en Brasil y otro en Argentina se encuentran protegidos. Finalmente, proponemos una serie de medidas que contribuyen a la preservación del Capuchino Pecho Blanco y de otras aves amenazadas que conviven con este.

\section{Introduction}

The genus Sporophila comprises about 30 species of small Neotropical birds highly specialised in the consumption of seeds (Meyer de Schaunensee 1952, Sick 1985, Ouellet 1992). They inhabit both forest and open habitats and many species are markedly migratory (Silva 1999). The 'capuchinos' (in Spanish) or 'caboclinhos' (in Portuguese) comprise a tightly-knit monophyletic group of species, several of which occur sympatrically, albeit in different habitats (Areta 2008, Areta and Repenning 2011, Areta et al. 2011), and they are among the most characteristic birds of the grasslands of south-eastern and central South America (Lijtmaer et al. 2004, Areta 2008, Campagna et al. 2010, Azpiroz et al. 2012). 
The natural history of the capuchinos has been poorly documented and the breeding biology of several species of this group remains poorly understood. The few studies include the Chestnut Seedeater Sporophila cinnamomea (Narosky 1973), Dark-throated Seedeater S. ruficollis (de la Peña 1981, 2005, 2009), Tawny-bellied Seedeater S. hypoxantha (de la Peña 2005, 2009, Di Giacomo 2005a, Facchinetti et al. 2008), Rufous-Rumped Seedeater S. hypochroma (Roda and López-Lanús 2008), Ruddy-breasted Seedeater S. minuta (ffrench 1980, Stiles and Skutch 1989) and Black-Bellied Seedeater S. melanogaster (Rovedder and Fontana 2012).

The capuchinos are of high conservation interest: over half are classified as globally "Endangered" (three species) or "Near Threatened" (three species) (BirdLife International 2013). Habitat loss and modification and, in some cases, trapping for the illegal cage-bird market are the main threats (BirdLife International 2013). Due to the high association of the endangered species of this group with the threatened natural grasslands of south-eastern South America (Azpiroz et al. 2012), the capuchinos are considered 'indicator species' for the identification of sites of conservation interest such as Important Bird Areas (Devenish et al. 2009) and Endemic Bird Areas (Stattersfield et al. 1998).

The Marsh Seedeater Sporophila palustris is the most threatened of the capuchinos, being listed as "Endangered" (BirdLife International 2013). This species includes the Entre Rios Seedeater S. zelichi, previously classified as "Critically Endangered" and now considered as a morph of the Marsh Seedeater or, less likely, a hybrid (Areta 2008). The Marsh Seedeater is a long distance migrant $(>1000 \mathrm{~km})$, breeding in temperate grasslands and marshes of north-east Argentina, southern Brazil and Uruguay and spending the non-breeding season in tropical grasslands of the central Brazilian Cerrado (Sick 1985, Collar et al. 1992, Silva 1999, Lima 2008, Areta 2008, BirdLife International 2013). The destruction of natural grassland ecosystems in South America is intensifying (Develey et al. 2008, Lopes et al. 2010, Azpiroz et al. 2012), and the conservation status of the Marsh Seedeater could worsen if efforts to protect habitats and populations are not implemented. The development of effective conservation actions for the species is further hampered by the lack of basic information on reproduction and ecological demands during the breeding and wintering seasons (Ridgely and Tudor 1989, Collar et al. 1992, Bencke et al. 2003, Areta 2008).

In this paper we describe the breeding biology and nesting habitats of the Marsh Seedeater, focusing on nest, eggs, clutch size, breeding period, parental care, nest building, courtship and food items consumed by adults. Based on our findings we recommend actions for the conservation of breeding populations.

\section{Methods}

Breeding data were collected in north-east Argentina (Corrientes and Entre Ríos provinces) between 2000 and 2007 and in southern Brazil (Rio Grande do Sul state) between 2008 and 2010. Nests were found through active searches in areas defended by territorial males or by following individuals carrying nest-building items or food for nestlings (Martin and Geupel 1993).

Breeding sites were described on the basis of vegetation composition, presence and intensity of agriculture, livestock, and exotic plants, and evidence of recent fires. Nests were monitored on consecutive days when possible. Measurements of nests and eggs were taken with a calliper to the nearest $0.1 \mathrm{~mm}$ and eggs were weighted using a scale accurate to $0.1 \mathrm{~g}$.

We used the method of 'focal observation' (Altmann 1974) to quantify nesting behaviour. We spent a total of $\mathrm{I}$ h monitoring nests under construction; $6 \mathrm{~h} 30 \mathrm{~min}$ during the incubation phase; I4 $\mathrm{h}$ during the nestling phase; and $2 \mathrm{~h}$ 10 min observing non-emancipated fledglings. During the observations we recorded the sex, behaviour, number of visits and intervals of absence of the parents. During the nestling and non-emancipated fledgling phases, we observed the food items collected and, for nestling phase, we estimated the distance of food collection from the nest by the parents in each trip. Two inactive nests and two eggs from Brazil were collected and deposited in the Museu de Ciências e Tecnologia of Pontifícia Universidade Católica do Rio Grande do Sul (MCT-PUCRS) (Table I). 


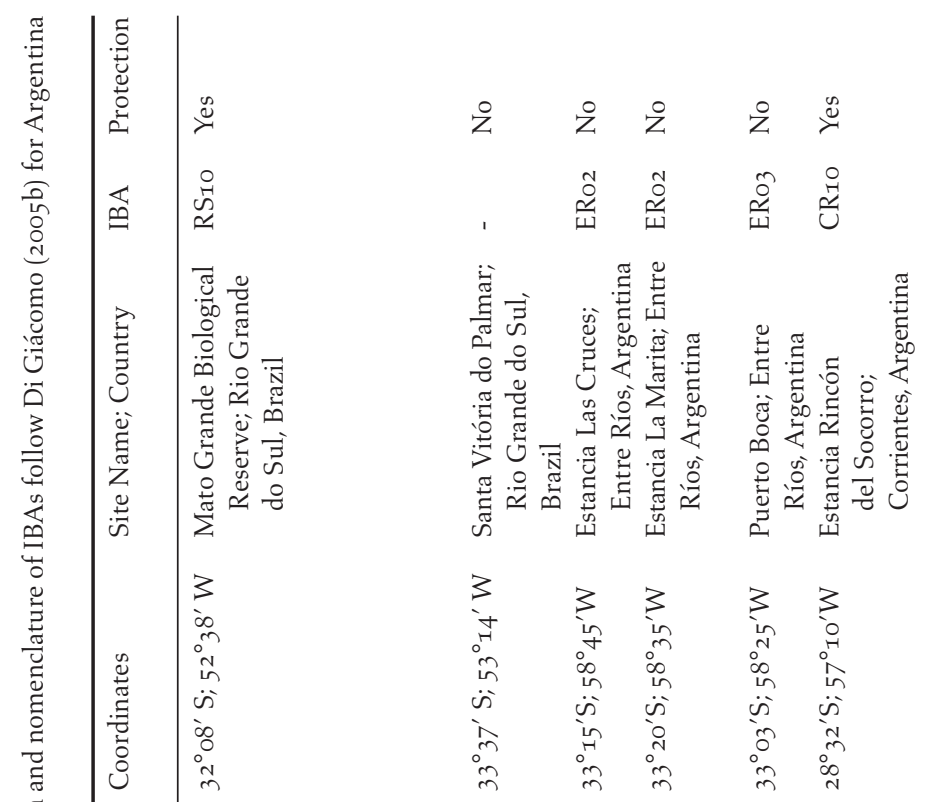

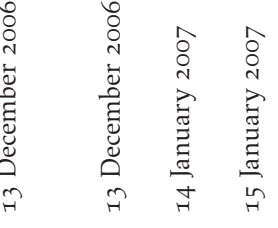

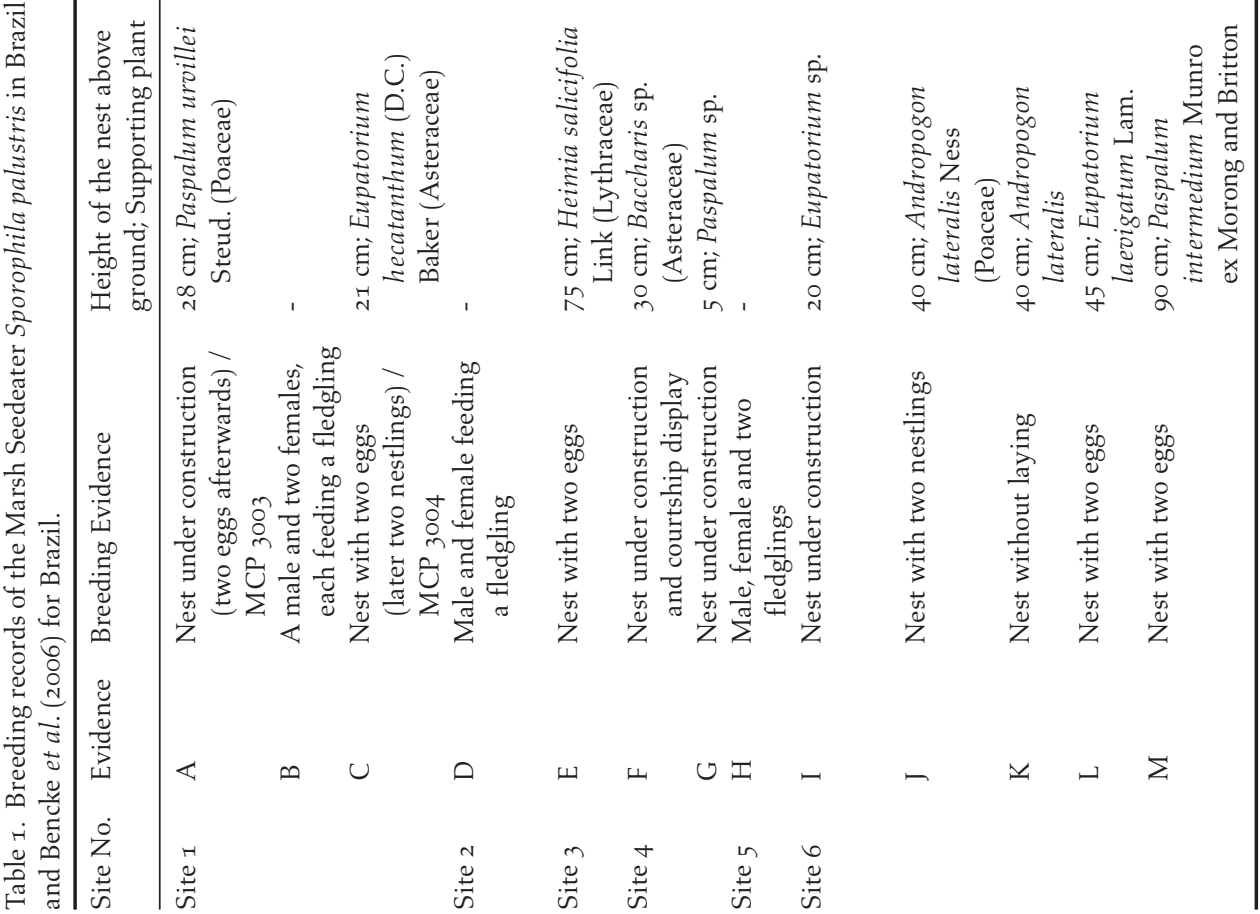




\section{Results}

We obtained nine breeding records of the Marsh Seedeater in four sites in Argentina and four breeding records in two sites in Brazil (Figure 1 , Table 1 ). A letter code was assigned to each record and is used throughout the manuscript (A to M; Table I).

\section{Breeding behaviour}

Food items. Adult Marsh Seedeaters were observed feeding on native grasses (Poaceae) that were remarkably abundant in the breeding sites. In Brazilian sites, seeds of Paspalum urvillei, Setaria parviflora, Eriochloa punctata and Digitaria sp. were consumed. In Argentine sites, seeds of Paspalum intermedium, P. notatum, P. plicatulum, P. urvillei and Andropogon lateralis were taken. We did not observe consumption of arthropods.

Courtship display. ( $n=1$, evidence F); One adult male was seen vibrating the wings quickly with a shallow quivering while raising the tail. This behaviour was repeated while the male flew among four different perches 7-10 $\mathrm{m}$ apart from each other, describing a circle around the female, which remained perched motionless. On some occasions the male sang while performing this display.

Nest building. ( $n=4$ nests; evidence A, F, G and I); Only the female built the nest, incorporating material every $4.4 \mathrm{~min}$ on average (range: $2-17 \mathrm{~min} ; n=15$ trips; nest $\mathrm{G}$ ). Materials were gathered close to the nest (mean $=23 \mathrm{~m}$; range $=12-40 \mathrm{~m}, n=4$ trips). The male remained near the nest always in silence. The male followed the female only during the farthest trips, but never accompanied her to the nest. On one occasion (evidence I) the male vocalised frequently, always perching higher than the female and at least $8 \mathrm{~m}$ away from the nest while she incorporated material. The female reached the nest through low direct flights and uttered a soft chac-chac-chac-chac-chac when arriving and leaving.

Parental care. Only the female incubated ( $n=3$ nests; evidence C, L and M). Incubation bouts averaged $23.1 \pm 16.9 \mathrm{~min}(n=12$ bouts; evidence C). Both sexes fed nestlings and fledglings $(n=4$; evidences B, C, D and J). The female made more feeding trips than the male ( $n=59$ vs 33 trips; nest C).

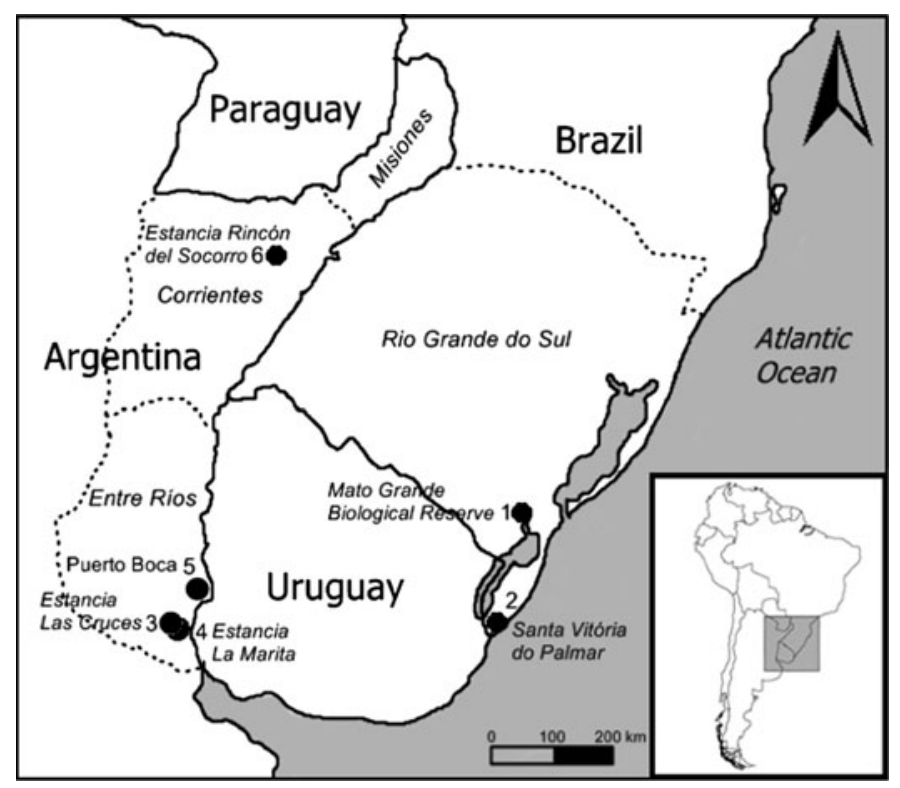

Figure 1. Map of the breeding sites (black dots) of the Marsh Seedeater Sporophila palustris in Brazil and Argentina reported in this study. 
Food provided to nestlings was obtained $46.5 \pm 27.7 \mathrm{~m}$ from the nest ( $n=80$ trips; evidence $\mathrm{C}$ ). Only seven times did parents travel more than $100 \mathrm{~m}$ from the nest. The nestlings and fledglings were fed with native grass seeds.

\section{Descriptive accounts}

Breeding period. One nest was found in November, four in December, seven in January and one in February. The earliest active nest was found on 21 November (evidence F) and the latest on 10 February (evidence C).

Nests. Nests were high cups supported by laterals (sensu Simon and Pacheco 2005). They were made of the dry panicles of native grasses such as Paspalum, Setaria and Briza from which the seeds were removed. These panicles were horizontally braided and laterally fixed to branches and leaves of supporting plants. Nests did not show a distinct lining, except for material inside which was visibly thinner. Nests were supported by $4-8$ branches (or leaves) of supporting plants. Two nests had abundant spiders' webs that reinforced the top edge of the nest and the area where it was attached to branches and leaves of the supporting plant. The general colour of the nests was tawny and the construction was firm. Four nests were located in clumps of native grasses (three species) and three in clumps of native broad-leaved herbaceous plants (two Asteraceae and one in Lythraceae). Nests were constructed $41.6 \pm 26.4 \mathrm{~cm}$ above ground ( $n=9$ nests). The dimensions of the nests were: outside diameter $6.05 \pm 0.60 \mathrm{~cm}$, inner diameter $4.67 \pm 0.87 \mathrm{~cm}$, height $5.30 \pm$ $0.85 \mathrm{~cm}$ and depth $4.55 \pm 0.53$ ( $n=7$ nests; Table 1 ). In general, nests in herbaceous plants were more conspicuous than those built in clumps of grasses.

Eggs. The eggs ( $n=4$; evidence A and C) were light grey or light blue with irregular brown and dark grey spots up to $4 \mathrm{~mm}$. Spots were more numerous and larger at the obtuse pole, where black dots or lines were found. The eggs were $16.7 \pm 0.6 \mathrm{~mm}$ long (range $=15.7-17.5 \mathrm{~mm}, n=8$ ), $12.2 \pm$ $0.4 \mathrm{~mm}$ wide (range $=11.7-12.7 \mathrm{~mm}, n=8)$ and weighed $1.2 \pm 0.2 \mathrm{~g}$ (range $=1.0-1.5 \mathrm{~g}, n=8)$.

Clutch Size. All nests invariably contained two eggs or two nestlings ( $n=6$ nests). Other records suggests this same clutch size: one male fed two fledglings (evidence B), two presumed Marsh Seedeater females fed two fledglings each (evidence B), a male and female had two fledglings (evidence $\mathrm{H}$ ). Only on one occasion a pair fed only one fledgling (evidence D).

Breeding habitat. Both sites in Brazil were wet grasslands located on flat soils close to permanently flooded wetlands covered by large stands of tall Cyperaceae on the margins of large freshwater lagoons. These grasslands are mainly composed by native grasses of the genera Paspalum, Setaria, Eriochloa with tussocks of Panicum prionitis (Poaceae) and clumps of Eryngium pandanifolium (Apiaceae). Broad-leaved plants (Baccharis and Eupatorium; Asteraceae) which are used by Marsh Seedeater to support the nests were notably common. Both breeding sites were flooded during the winter. Presence of cattle was low year-round. Both sites were partially burned in the range of I-2 years before the breeding events. Comparatively higher terrain surrounding wetlands is used for cattle raising and rice growing.

In Entre Ríos, Argentina, nesting sites were located in grasslands used by livestock. The topography is undulating, with well-drained soil and crossed by shallow streams. The Marsh Seedeaters nested in wet grassland marginal to these streams where floods occur occasionally. These grasslands had a layer of tall grasses and bushes (Paspalum intermedium, P. plicatulum and Sorghastrum sp.) and a lower layer of grasses such as Panicum hians, Paspalum dilatatum and Briza sp. Among the broad-leaved plants tall species such as Eryngium pandanifolium and several shrubs of the genus Baccharis and Eupatorium occurred. In these sites, Panicum prionites was the dominant species in the flooding areas at lower elevations. Currently, these grasslands in Entre Ríos cover only small areas within an intensive agricultural matrix of crops, exotic pastures and afforestation.

In Corrientes, the Marsh Seedeater nested in grasslands locally denominated 'malezales'. This plant community is almost uniformly dominated by Andropogon lateralis and occurs on ground with slightly undulating topography, poorly drained soils and the presence of water during long 
periods of the year. These grasslands alternate with extensive wetlands dominated by other grasses of the genera Panicum and Paspalum and sedges such as Rhynchospora corymbosa. Currently, most of these grasslands in Corrientes are under livestock activity with widespread use of fire (annually), even at higher elevation areas of large scale silviculture.

\section{Discussion}

\section{Breeding biology}

The breeding season of the Marsh Seedeater extends from November (after arrival at breeding sites) until at least late February. From February to mid-April, the number of individuals reduces gradually (JIA, JVB pers. obs.). This timing of breeding and migration is shared by most species of capuchinos in our study area (e.g. Belton 1994, Bencke et al. 2003, de la Peña 2005; Di Giacomo 2005a, Roda and López-Lanús 2008).

By building their nests in tussocks of native grasses, the Marsh Seedeater differs from the other capuchinos, which basically use broad-leaved herbaceous plants to support their nests (mainly Asteraceae and Fabaceae), including some exotic species and crop weeds (Di Giacomo 2005a, Roda and López-Lanús 2008, de la Peña 2005, 2009, Rovedder and Fontana 2012). Among the capuchinos, only the Ruddy-breasted Seedeater also uses grass-tussocks for nesting (see also ffrench 1980, Stiles and Skutch 1989) and occasionally Tawny-bellied and Chestnut Seedeaters (AGD, ASD pers. obs.).

The size of Marsh Seedeater nests, the materials used in construction, the location and height above the ground are very similar to those known for other capuchinos (Narosky 1973, de la Peña 1981, 2005, 2009, ffrench 1980, Di Giacomo 2005a, Roda and Lopez-Lanús 2008, Rovedder and Fontana 2012), including a nest of Marsh Seedeater from a site close to ours in Entre Ríos, Argentina that was described briefly by Chebez et al. (2008). Clutch size, egg colour and parental behaviour, including more female care to offspring, are also similar to those of other capuchinos (e.g. ffrench 1980, Di Giacomo 2005a, Facchinetti et al. 2008).

Nesting sites of the Marsh Seedeater described in this study were located in wet grasslands situated in transition zones between terrestrial and aquatic habitats. In this sense, the species does not nest in marshes proper, but rather on their margins. The vegetation is characterised by a matrix of grasses arranged in clumps about $1 \mathrm{~m}$ high in a vegetative state (mainly Andropogon, Panicum and Paspalum) and numerous shrubs (mainly Baccharis and Eupatorium). The soils are permanently or seasonally flooded during the period of highest rainfall in the austral winter (pers. obs.). All sites in Brazil and Entre Ríos province also are characterised by the presence of dense patches of Eryngium pandanifolium.

\section{Breeding data and conservation implications}

The Marsh Seedeater was found breeding in wet and seasonally flooded grasslands in southern Brazil and north-eastern Argentina. The species is also known to breed at the 'Banhado do Maçarico' (IBA RSII) in southern Brazil, where a small fledgling was found on 9 January 2003 (Bencke et al. 2003). Nesting is also likely in eastern and western Uruguay and at the 'Banhado São Donato' (IBA RSo2) in southern Brazil, which have adequate breeding habitats (Bencke et al. 2006, Areta 2008). The breeding habitats have a highly fragmented distribution and most of the breeding sites are contained in an Endemic Bird Area (EBA): Argentine Mesopotamian grasslands (Stattersfield et al. 1998). Five of the six sites reported in this study (one in Brazil and four in Argentina) are recognised as Important Bird Areas (IBAs), but only one in Brazil and another in Argentina are under some kind of protection (Table 1 ). The Marsh Seedeater is sympatric with populations of other globally threatened ("Vulnerable") grassland species such as Strange-tailed Tyrant Alectrurus risora and Sharp-tailed Tyrant Culicivora caudacuta in Argentina, and Black-andwhite Monjita Xolmis dominicanus, Ochre-breasted Pipit Anthus nattereri, Chestnut Seedeater 
Sporophila cinnamomea and Saffron-cowled Blackbird Xanthopsar flavus in Argentina and Brazil (Di Giacomo 2005b, Bencke et al. 2006, pers. obs.). Thus, the establishment of protection measures for breeding populations of Marsh Seedeater will indirectly benefit several other globally threatened species.

\section{Main threats to Marsh Seedeater in breeding areas}

Habitat loss. Four activities that promote habitat loss or modification were recognized. I) Overgrazing. Livestock rearing is the main economic activity in Marsh Seedeater breeding sites. However, the species was recorded breeding only in areas with low cattle density where the vegetation remains tall. Grasslands used for livestock usually suffer from excessive trampling and overgrazing which notably reduces the height of the vegetation and the availability of seeds, becoming unsuitable for the reproduction of Marsh Seedeaters. 2) Planted pastures. Recently, the extensive (and traditional) livestock have been gradually replaced by semi-intensive or intensive livestock in north-east Argentina, with native pastures replaced by planted pastures of exotic grasses (Azpiroz et al. 2012). Marsh Seedeaters and other globally threatened grassland birds were absent from sites where native vegetation has been replaced by planted pastures (Di Giacomo et al. 2010). However, all species maintained breeding populations in native grasslands with low trampling where the vegetation surrounding the wetlands was $0.5-1 \mathrm{~m}$ high. 3) Irrigated rice fields. In southern Brazil and north-east Argentina, wet grasslands were converted into rice fields or have their hydrological cycles affected by the use of freshwater from marshes or from natural and artificial reservoirs nearby (Bencke et al. 2003, JVB pers. obs.). 4) Afforestation. A recent threat is the rapid increase of Eucalyptus and Pinus afforestation in south-eastern South America (Di Giacomo and Krapovickas 2001, Azpiroz et al. 2012), which fragments and eliminates grasslands and reduces the connectivity between them (Bencke et al. 2003, Di Giacomo 2005b, Di Giacomo et al. 2010), in turn reducing the availability of resources for migratory birds such as the Marsh Seedeater (Areta 2008).

Fire. The use of fire is a traditional practice that stimulates production of fresh plant biomass which is used as natural forage for cattle (Morello and Adamoli 1974, Kunst and Bravo 2003, Di Bella et al. 2006). Fire and grazing are considered fundamental natural disturbances that promote maintenance of grasslands (Overbeck et al. 2007). However, the most widely used fire-management practice sets fires at a higher rate (once or more per year) than naturally occurring fires (once every four years) (see Kunst and Bravo 2003). In Corrientes, artificial fires occur year-long even during the breeding season of Marsh Seedeaters (JIA, AGD and ASD pers. obs.). Fire was also observed in southern Brazil during the breeding season, especially in very dry summers (JVB, FJ, MAAC and RAD pers. obs.). Available information on the effects of fire on grassland birds of southern South America are scarce, but recent studies on species that coexist with Marsh Seedeaters have demonstrated direct implications for their conservation (JIA, AGD and ASD pers. obs.). For example, the Saffron-cowled Blackbird returns only after three breeding seasons once the vegetation reaches advanced stages of regeneration (Petry and Kruger 2010), and the Strange-tailed Tyrant requires at least two seasons to return to reproduce in burned areas (Di Giacomo et al. 2011). While infrequent burning can benefit grassland birds by maintaining grassland habitats free from invading shrubs, frequent fires can have adverse effects if they occur during the reproductive period. Marsh Seedeaters are notably vulnerable to fire due to the location of nests in clumps of grasses close to the ground.

Cage bird market. The Marsh Seedeater and other capuchinos are very popular cage birds (Lima 2008, BirdLife International 2013). Males are caught in large numbers and the effect on populations is unknown (Areta 2008). The illegal trapping of individuals is facilitated by the territorial behaviour of males and their conspicuous presence along rural roads (Willis and Oniki 1993, pers. obs.). The illegal capture appears to be a very important factor in the decline of populations in sites in Entre Ríos, Argentina. Capture of capuchinos is a popular activity in this province in which 'expert' trappers have existed for decades (Narosky 1977, JIA, AGD and ASD pers. obs.). 
Despite little enforcement, 15 capuchinos, including Marsh Seedeaters, were confiscated in a small region of Entre Ríos during a breeding season (October 2004-March 2005). These birds had been used by trappers as attractors to capture other individuals (Anonymous 2005). Informal surveys in Entre Rios in a single season resulted in over 20 Marsh Seedeaters found among bird-trappers, including a single S. "zelichi" which was used to call Marsh Seedeaters to their traps (JIA pers. obs.). In Rio Grande do Sul, the available data suggest that this problem is less severe. Only five males were received between 2000 and 2012 in the wildlife rehabilitation center of the Universidade Federal de Pelotas (Núcleo de Reabilitação da Fauna Silvestre - UFPEL), one of the main institutions receiving wildlife confiscated from the illegal trade in southern Brazil (MAAC pers. obs.).

\section{Concluding remarks and recommendations}

This study indicates that effective conservation of Marsh Seedeaters depends critically on maintaining the integrity of temperate wet grasslands where this species reproduces. We describe a range of increasing problems and threats to the conservation of breeding habitats of the Marsh Seedeater and other coexisting endangered species.

Existing protected areas are insufficient to support viable populations of this species. Remaining areas are being continuously altered or destroyed by several economic activities and may cause Marsh Seedeater populations to decline or become locally extinct. In north-east Argentina, more than one million ha of grasslands were identified as IBAs, but only c.10\% of this area is under some kind of protection or management (Di Giacomo et al. 2011). In southern Brazil, more than 500,000 ha were identified as IBAs in grasslands of Rio Grande do Sul, of which only c.12\% is under some kind of protection (Bencke et al. 2006).

In this context, we propose measures that should be urgently implemented in order to conserve breeding populations of the Marsh Seedeater and other birds which share grassland habitats.

1) Restrict grazing by means of management or exclusion of cattle in wet grasslands that are effective or potential breeding sites. We propose a tentative distance of at least $100 \mathrm{~m}$ around marshes based on our experience in the field until more complete studies are available.

2) Restrict afforestation and planting of pastures of introduced grasses.

3) Encourage and support extensive livestock raising in natural pastures (e.g. by means of projects such as 'Pastizales del Cono Sur' http://www.pastizalesdelconosur.org or 'Producción Responsable' http://www.cebra.com.uy/presponsable/; see Develey et al. 2008 and Azpiroz et al. 2012) instead of activities that promote the destruction of grasslands.

3) Ensure compliance with environmental legislation for activities that affect hydrological cycles of wet grasslands and alter the structure of the vegetation and availability of feeding resources.

4) Develop fire management plans considering the use of a mosaic of controlled burns. In IBAs where the species is present, fires should be set outside the breeding season and with a frequency greater than two years to allow the development of dense vegetation. In Argentina the law on minimum prescribed fires should be implemented.

5) Prosecute trappers more intensively, especially between November and April, and alert society on the negative effects of the cage-bird market on populations of target species.

6) Establish protected areas in IBAs where the species breeds in Argentina: Perdices (ERo2), Rincón del Socorro-Iberá (CRıo) and grasslands in the Reserva Provincial del Iberá, and Brazil: Banhado do Maçarico (RSII) and the Várzea do Canal São Gonçalo (RSıIo), including the effective implementation of the 'Mato Grande' Biological Reserve located in the south-western border of the latter. 


\section{Acknowledgements}

We thank Andrew MacDonald for reviewing the English in the manuscript. Raquel Lüdtke provided the identification of grasses from Brazil. Cristian M. Joenck, Paulo R. Post and Vinícius A. G. Bastazini helped us during fieldwork in Brazil, and Ariel Ocampo in Argentina. We also thank Aves Argentinas, University of Buenos Aires, Alparamis S. A. and Conservation Land Trust for supporting this study in Argentina. JVB, MAAC, FJ and RAD also thank the Grupo Ecológico Amantes da Natureza for their encouragement and assistance in the study. JVB was supported by a Conselho Nacional de Desenvolvimento Científico e Tecnológico grant and Universidade Federal de Pelotas. JIA and ASDG were supported by the Consejo Nacional de Investigaciones Científicas y Técnicas. RAD was supported by the research programme of the Universidade Católica de Pelotas and SAVE Brasil.

\section{References}

Altmann, S. A. (1974) Observational study of behaviour: sampling methods. Behavior 49: 227-265.

Areta, J. I. (2008) Sporophila zelichi: a species that never was. J. Field Ornithol. 79: $352-363$.

Areta, J. I., Noriega, J. I., Pagano, L. and Roesler, I.. (2011) Unraveling the ecological radiation of the capuchinos: systematics of the Dark-throated Seedeater Sporophila ruficollis, and description of a new blackcollared form. Bull. Brit. Ornithol. Club 131: 4-23.

Areta, J. I. and Repenning, M. (2011) Systematics of the Tawny-bellied Seedeater (Sporophila hypoxantha). I. Geographic variation, ecology and evolution of vocalizations. Condor 113: 664-677.

Anonymous. (2005). Exitosa campaña para controlar el furtivismo. Nuestras Aves 49: 4 .

Azpiroz, A. B., Isacch, J. P., Dias, R. A., Di Giacomo, A. S., Fontana, C. S. and Palarea, C. M. (2012) Ecology and conservation of grassland birds in southeastern South America: a review. J. Field Ornithol. 83: 217-246.

Belton, W. (1994) Aves do Rio Grande do Sul, distribuição e biologia. São Leopoldo, Brazil: Ed. Unisinos.

Bencke, G. A., Fontana, C. S., Maurício, G. N., Dias, R. A. and Mähler, J. K. F, Jr. (2003) Aves. Pp. $189-479$ in C. S. Fontana, G. A. Bencke and R. E. Reis, eds. Livro vermelho da fauna ameaçada de extinção no Rio Grande do Sul. Porto Alegre, Brazil: EDIPUCRS.

Bencke, G. A., Maurício, G. N., Develey, P. F. and Goerck, J. M., eds. (2006) Áreas importantes para a conservação das aves no Brasil. Parte 1-Estados do Domínio da Mata Atlântica. São Paulo, Brazil: SAVE Brasil.

BirdLife International (2013) Species factsheet: Sporophila palustris. Downloaded from http://www.birdlife.org on 06/02/2013.

Campagna, L., Lijtmaer, D. A., Kerr, K. C. R., Barreira, A. S., Hebert, P. D. N, Lougheed and Tubaro, P. L. (2010) DNA barcodes provide new evidence of a recent radiation in the genus Sporophila (Aves: Passeriformes). Mol. Ecol. Resources 10: 449-458.

Chebez, J. C., Rodriguez, L. and Narosky, T. (2008) "Capuchino pecho blanco". Pp. 375378 in J. C. Chebez, ed. Los que se van. Fauna argentina amenazada. Tomo 2. Buenos Aires, Argentina: Albatros.

Collar, N. J., Gonzaga, L. P., Krabbe, N., Madroño Nieto, A., Naranjo, L. G., Parker, T. A. and Wege, D. C. (1992) Threatened birds of the Americas: The ICBP/IUCN Red Data Book. Cambridge, UK: International Council for Bird Preservation.

de la Peña, M. R. (1981) Notas nidobiológicas sobre corbatitas (Aves, Emberizidae): segunda parte. Hist. Nat. 2: 45-48.

de la Peña, M. R. (2005) Reproducción de las aves argentinas (con descripción de pichones). Buenos Aires, Argentina: LOLA. (Monografía 20).

de la Peña, M. R. (2009) Observaciones sobre la biología y situación del Capuchino Canela (Sporophila hypoxantha) y el Capuchino Garganta Café (Sporophila ruficollis) en áreas del espinal del Departamente Las Colonias, Provincia de Santa Fé, Argentina. Biológica 10: 62-63. 
Develey, P. F., Setubal, R, B., Dias, R. A. and Bencke, G. A. (2008) Conservação das aves e da biodiversidade no bioma Pampa aliada a sistemas de produção animal. Rev.Bras. Ornitol. 16: 308-315.

Devenish, C., Díaz Fernández, D. F., Clay, R. P., Davidson, I. J. and Yépez Zabala, I. (2009) Important Bird Areas Americas - Priority sites for biodiversity conservation. Quito, Ecuador: BirdLife International. (BirdLife Conservation Series $N^{\circ} 16$ ).

Di Bella, C. M., Jobbágy, E. G., Paruelo, J. M. and Pinnock, S. (2006) Continental FIRE density in South America. Global Ecol. Biogeog. 15: 192-199.

Di Giacomo, A. G. (2005a) Aves de la Reserva El Bagual. Pp. 201-465in A. G. Di Giacomo and S. F. Krapovickas, eds. (2005). Historia natural y paisaje de la Reserva El Bagual, provincia de Formosa. Inventario de la fauna de vertebrados y de la flora vascular de un área protegida del Chaco Húmedo. Temas de Naturaleza y Conservación 4: 1-592. Buenos Aires, Argentina: Aves Argentinas / Asociación Ornitológica del Plata.

Di Giacomo, A. S. and Krapovickas, S. (2001) Afforestation threatens Argentina's grasslands. World Birdwatch 23: 24-25.

Di Giacomo, A. S. (2005b) Áreas importantes para la conservación de las aves en la Argentina. Sitios prioritarios para la conservación de la biodiversidad. Temas de Naturaleza y Conservación 5: 1-514. Buenos Aires, Argentina: Aves Argentinas / Asociación Ornitológica del Plata.

Di Giacomo, A. G., Di Giacomo, A. S. and Reboreda, J. C. (2011) Effects of grassland burning on reproductive success of globally threatened Strange-tailed Tyrant Alectrurus risora. Bird Conserv. Internatn. 21: 411-422.

Di Giacomo, A. S., Vickery, P. D., Casañas, H., Spitznagel, O. A., Ostrosky, C., Kaprovickas, S. and Bosso, A. J. (2010) Landscape associations of globally threatened grassland birds in the Aguapey river Important Bird Area, Corrientes, Argentina. Bird Conserv. Internatn. 20: 62-73.

Facchinetti, C., Di Giacomo, A. G. and Reboreda, J. C. (2008) Parental care in Tawny-bellied (Sporophila hypoxantha) and Rusty-collared (S. collaris) Seedeaters. Wilson J. Ornith. 120: 879-883. ffrench, R. P. (1980) A guide to the birds of Trinidad and Tobago. Pennsylvania: Harrowood Books.

Kunst, C. R. and Bravo, S. (2003) Ecología y regimen de fuego en la región chaqueña argentina. Pp. 109-118 in C. R. Kunst, S. Bravo and J. L. Panigatti, eds. Fuego en los ecosistemas argentinos. Santiago del Estero, Argentina: Ed. INTA.

Lijtmaer, D. A., Sharpe, N. M. M., Tubaro, P. L. and Loughedd, S. C. (2004) Molecular phylogenetics and diversification of the genus Sporophila (Aves: Passeriformes). Mol. Phyl. Evol. 33: 562-579.

Lima, É. M. C. (2008) Sporophila palustris (Barrows, 1883). Pp. 549-550 in A. B. M. Machado, G. M. Drumond and A. P. Paglia, eds. Livro vermelho da fauna brasileira ameaçada de extinção (Vol. 2). Brasília and Belo Horizonte, Brazil: Ministério do Meio Ambiente and Fundação Biodiversitas. (Série Biodiversidade número 19).

Lopes, L. E., Malacco, G. B., Alteff, E. F., Vasconcelos, M. F., Hoffmann, D. and Silveira, L. F. (2010) Range extensions and conservation of some threatened or little known Brazilian grassland birds. Bird Conserv. Internatn. 20:84-94.

Martin, T. E. and Geupel, G. R. (1993) Nestmonitoring plots: methods for locating nests and monitoring success. J. Field Ornith. 64: 507-519.

Meyer de Schauensee, R. (1952) A review of the genus Sporophila. Proc. Acad. Nat. Sci. Philadelphia 104: 153-196.

Morello, J. and Adamoli, J. (1974) Las grandes unidades de vegetación y ambiente del Chaco Argentino. Segunda Parte: Vegetación y ambiente de la provincia de Chaco. Buenos Aires, Argentina: INTA. (Serie Fitogeográfica $\mathrm{N}^{\circ}$ 8: 1-130).

Narosky, S. (1973) Una nueva especie de Sporophila para la avifauna argentina. Hornero 11: 169-171.

Narosky, S. (1977) Una nueva especie del género Sporophila (Emberizidea). Hornero 11: 345-348.

Ouellet, H. (1992) Speciation, zoogeography and taxonomic problems in the Neotropical genus Sporophila (Aves: Emberizinae). Bull. Br. Ornithol. Club Centenary Suppl. 112A: 225-235. 
Overbeck, G. E., Müller, S. C., Fidelis, A., Pfadenhauer, J., Pillar, V. D., Blanco, C. C., Boldrini, I. I., Both, R. and Forneck, E. D. (2007) Brazil's neglected biome: The South Brazilian Campos. Perspect. Plant. Ecol. Evol. Syst. 9: 101-116.

Petry, M. V. and Kruger, L. (2010) Frequent use of burned grasslands by the vulnerable Saffron-Cowled Blackbird Xanthopsar flavus: implications for the conservation of the species. J. Ornithol. 151: 1-7.

Ridgely, R. S. and Tudor, G. (1989) The birds of South America. Vol. I. The oscine passerines. Austin, USA: University of Texas Press.

Roda, M. Á. and López-Lanús, B. (2008) The range of Rufous-rumped Seedeater Sporophila hypochroma extends to the Pampas region of Argentina, with the first nest of the species. Cotinga 30 : 61-62.

Rovedder, C. E. and Fontana, C. S. (2012) Nest, eggs, and nest placement of the Brazilian endemic Black-bellied Seedeater (Sporophila melanogaster). Wilson J. Ornith. 124: $173-176$.

Sick, H. (1985) Ornitologia Brasileira, uma introdução. Vol. 2. Brasilia, Brazil: Edit. Universidade de Brasília.

Silva, J. M. C. (1999) Seasonal movements and conservation of seedeaters of the genus Sporophila in South America. Stud. Avian Biol. 19: 272-280.

Simon, J. E. and Pacheco, S. (2005) On the standardization of nest descriptions of Neotropical birds. Rev. Bras. Ornitol. 13: 143-154.

Stattersfield, A. J., Crosby, M. J., Long, A. J. and Wege, D. C. (1998) Endemic Bird Areas of the world. Cambridge, UK: Birdlife International. (BirdLife Conservation Series $\mathrm{N}^{\circ} 7$ ).

Stiles, F. G. and Skutch, A. F. (1989) A guide to the birds of Costa Rica. Ithaca, New York: Cornell Univ. Press.

Willis, E. O. and Oniki, Y. (1993) New and reconfirmed birds from the state of São Paulo, Brazil, with notes on disappearing species. Bull. Br. Ornithol. Club 113: 23-24.

\section{JEFERSON VIZENTIN-BUGONI*}

Pós-graduação em Ecologia, Universidade Estadual de Campinas, CEP 13083-970, Campinas, São Paulo, Brazil.

JUAN I. ARETA

IBIGEO-CONICET, Mendoza 2 (4400), Salta, Argentina.

\section{ALEJANDRO G. DI GIACOMO}

Departamento de Conservación, Aves Argentinas/Asociación Ornitológica del Plata, Matheu 1246, C1249AAB, Buenos Aires, Argentina.

\section{ADRIAN S. DI GIACOMO}

Laboratorio de Ecología y Comportamiento Animal, Instituto de Ecología, Genética y Evolución de Buenos Aires (IEGEBA-CONICET), Facultad de Ciencias Exactas y Naturales, Universidad de Buenos Aires, Pabellón II Ciudad Universitaria, C1428EGA, Buenos Aires, Argentina.

\section{FERNANDO JACOBS}

Departamento de Zoologia e Genética, Instituto de Biologia, Universidade Federal de Pelotas, CEP 96010-900, Capão do Leão, Rio Grande do Sul, Brazil.

\section{MARCO A. AFONSO COIMBRA}

Núcleo de Reabilitação da Fauna Silvestre e Centro de Triagem de Animais Silvestres, Instituto de Biologia, Universidade Federal de Pelotas, CEP 96010-900, Capão do Leão, Rio Grande do Sul, Brazil. 


\section{RAFAEL A. DIAS}

Setor de Ornitologia, Laboratório de Biologia e Ecologia de Cordados, Universidade Católica de Pelotas, Rua Félix da Cunha 412, CEP 96010-000, Pelotas, Rio Grande do Sul, Brazil.

Current address: PPG em Ecologia, Instituto de Biociências, Universidade Federal do Rio Grande do Sul, Av. Bento Gonçalves 9500, setor 4, prédio 43422, CP 15007, CEP 91540-000, Porto Alegre, Rio Grande do Sul, Brazil.

*Author for correspondence; e-mail:jbugoni@yahoo.com.br

Received 7 June 2012; revision accepted 11 February 2013 